\title{
Scaling Up Your Story: An Experiment in Global Knowledge Sharing at the World Bank
}

\author{
Shad Morris \\ Brigham Young University, morris@byu.edu \\ James B. Oldroyd \\ Brigham Young University, oldroyd@byu.edu \\ Sita Ramaswami \\ International Finance Corporation
}

Follow this and additional works at: https://scholarsarchive.byu.edu/facpub

Part of the Finance and Financial Management Commons, and the Technology and Innovation

Commons

\section{Original Publication Citation}

Morris, S., Oldroyd, J., \& Ramaswami, S. 2016. Scaling Up Your Story: An Experiment in Global Knowledge Sharing at the World Bank. Long Range Planning, 49(1): 1-14.

\section{BYU ScholarsArchive Citation}

Morris, Shad; Oldroyd, James B.; and Ramaswami, Sita, "Scaling Up Your Story: An Experiment in Global Knowledge Sharing at the World Bank" (2016). Faculty Publications. 3679.

https://scholarsarchive.byu.edu/facpub/3679 
Scaling Up Your Story: An Experiment in Global Knowledge Sharing at the World Bank

\author{
Shad S. Morris, James B. Odroyd, Sita Ramaswami
}

\begin{abstract}
Timely and effective knowledge transfer is increasingly important in today's technologically advanced global market. However, a myopic focus on efficiency has frequently rendered most organizational knowledge ineffective. By coupling technology with a formal system that captures informal stories in an engaging and entertaining way, actors within an organization may be more willing to listen to what geographically dispersed colleagues are doing, and may be more likely to ascribe value to that information. Focusing on the International Finance Corporation of the World Bank Group, we conducted interviews with those sharing and using knowledge, and performed content analyses of 175 knowledge-sharing narratives. Our goal was to understand which aspects of narrative knowledge drive interest and value to users of that knowledge. We found that those seeking knowledge look to others in determining interest, but rely on the internal emotional content of the narrative in determining value. This finding suggests that the usefulness of knowledge is both socially and analytically constructed.
\end{abstract}

Keywords: Knowledge management; Knowledge transfer; Narratives, Information technology; Organizational capabilities; Emerging markets 


\section{Introduction}

Long ago, the people of Phrygia, an ancient kingdom in what is now western Turkey, found themselves without a king. An oracle decreed that the next man who entered the city driving an oxcart should ascend to the throne. This next man happened to be a peasant, Ahmidas, son of Gordias. Ahmidas, who was driving his parents into town on his father's oxcart, was surprised to be immediately declared king. In gratitude, he dedicated his now-sacred oxcart to the Phrygian god Sabazios, tying an intricate knot around the shaft of the cart. It was subsequently prophesied that the individual who untied the knot would become the king of Asia. The oxcart remained in the palace of the former kings of Phrygia at Gordium, until the year 333 B.C., when Alexander the Great arrived to make camp for the winter. While in Phrygia, Alexander made attempts to untie the knot. When he could find no end to the knot, with a quick stroke of his sword he sliced it in half, producing the loose ends that allowed him to untie it. Fulfilling the prophecy, Alexander went on to become the king of Asia (Fox, 1973).

The story of the Gordian Knot has been told and retold for over 2000 years. These retellings have served to transfer knowledge across ages, cultures and geographies - knowledge that has legitimized dynasties by affirming the right of conquest, and taught the value of creative and decisive thinking in solving difficult problems.

Narratives like this one have served as a potent form of knowledge transfer. Passed from one person to another, and down through generations, stories instruct and enlighten their listeners in an entertaining fashion. This history of knowledge transfer comes in sharp contrast to modern modes of knowledge management, which are largely sterile, technology-driven, hyper-efficient and all but devoid of context and human emotion (Fog et al., 2005). This transformation is likely a by-product of an increasing focus on massive codification and the proliferation of a technical 
architecture that seeks to identify and codify knowledge, locate its potential users, and measure, track and improve the performance effects of that use (Davenport, 2005).

Actors often employ technology-led knowledge management in efforts to solve the complex problems posed by a global environment composed of myriad points of information. Commonly, these actors attempt to apply the concept of economies of scale to knowledge sharing tools. This can be achieved by applying a single knowledge-sharing process to multiple parts of a given organization, and ensuring efficient sharing routines across geographical and other boundaries. Of course, this strategy is unsurprising, given the increased need for companies to better manage their knowledge. According to Stewart: "The companies that master the knowledge agenda are the companies that will triumph in the twenty-first century. Because ... knowledge has become the most important factor of production and knowledge assets the most powerful producers of wealth, the leaders and organizations that take command of their knowledge will occupy competition's high ground" (Stewart, 2001).

Yet these knowledge processes often prioritize only the codification of knowledge, much to the detriment of the user's valuation of the knowledge itself (Schreyögg and Geiger, 2005, 2007). In many cases, this approach results in a myopic organizational focus on knowledge availability efforts, attending only to efficiency-based concerns like codifying information, standardizing reporting, and developing information technologies (Snowden, 2003). Most technology-focused knowledge distribution efforts are similarly limited, in that they include a standard reporting system, are driven by top management, and are implemented-most often grudgingly—by staff.

It is therefore unsurprising that many knowledge management efforts prove largely unsuccessful; companies spend millions of dollars developing elaborate databases and processing 
manuals that are often greeted with yawns by their users. In fact, organizational employees worldwide complain about an overabundance of information that neither captures their interest nor creates value for them (Frank and Magnone, 2011). As one of our interviewees stated, "There are too many web sites and too much information for anyone to really process anything useful."

In response to such hyper-efficient yet underutilized technologies, some scholars have recently called for a refocus on narrative forms of knowledge transfer (De Geus, 1997; Denning, 2000; Shaw et al., 1998; Swap et al., 2001). But, the media used for effective transfer of narrative knowledge typically require direct and costly person-to-person interactions. These processes are predominantly bottom-up, people-intensive, and typically endorse solutions like communities of practice, informal collaboration, and flexible work environments that allow for both knowledge sharing and interpersonal connection (Brown and Duguid, 2000). These programs create interest and value by connecting the user directly to the knowledge source on a personal, emotional level (Brown and Duguid, 2000).

For example, McKinsey Consulting Company has championed precisely this sort of hypereffective knowledge transfer system. Employees of the firm are encouraged to pick up the phone and call one another, utilizing direct, interpersonal interaction in transferring the complex knowledge embedded in prior consulting projects. For instance, one manager noted that "at promotion time, nobody reviewed your PD documents (Project Development documents, a type of knowledge codification effort). They looked at how you used your internal networks to have your ideas make an impact on clients" (Bartlett, 1996).

For all the advantages of such an interpersonal system, though, an increased dependency on narrative can create inefficiencies that ultimately stifle the flow of knowledge. Some consider these systems too "time consuming" and "logistically challenging," which are both legitimate 
concerns. In a firm with thousands of employees dispersed across the globe, achieving broad and direct interpersonal connections can be virtually impossible, even with access to advanced information technologies. As a result, these more personal, interactive knowledge management practices are often incompatible with necessary economies of scale and scope, which can be a damning flaw in today's global business environment (Cohen et al., 2006). In reaction, person-toperson knowledge distribution mechanisms often lose their impact-and may even foster information silos_-in firm divisions, regions and countries in which knowledge is well-circulated locally (Morris et al., 2006).

It is little wonder, then, that narrative knowledge management systems so often fail to do what companies want them to do- that is, to distribute relevant and valuable information to individuals as quickly as possible and on a global scale. Ultimately, accomplishing this goal requires an ability to codify narratives without diminishing their usefulness.

In this paper, we explore what drives actors' interest in the knowledge content and what determines how they perceive the value of narratives within a multinational enterprise (MNE). We begin by discussing the importance of knowledge for the MNE, as well as the difficulties inherent in transferring knowledge across geographical borders. We then explore the factors that determine the interest in and the use of narratives within the MNE. Following this discussion, we test our predictions using a unique data set from the International Finance Corporation of the World Bank Group, that details how certain types of codified narratives might be able to capture interest and produce value across geographic divides. Finally, we discuss the results, implications, and future directions for our research.

The Value of Cross-Border Knowledge Transfer 
The typical MNE can leverage its store of geographically dispersed knowledge to gain a competitive advantage. The key to this advantage is the availability of heterogeneous ideas across distant locations (Ambos and Ambos, 2009; Foss and Pedersen, 2004). Because MNEs operate in multiple countries and regions, the knowledge they produce reflects unique contextual circumstances embedded in geographic divides, local requirements, laws, cultures and the like (Doz and Santos, 1997). Indeed, local knowledge lies at the heart of the MNE's ability to produce heterogeneous knowledge. By exchanging and combining this locally diverse knowledge across various boundaries, the MNE can identify solutions from one local context and apply them in another (Bartlett and Ghoshal, 1989). Employees who are able to use nonlocal knowledge effectively for their own work within the MNE, then, will provide particular value to the organization (Cantwell and Mudambi, 2005; Kogut and Zander, 2003).

Highly dispersed knowledge is most efficiently transferred when it is first captured in electronic databases, manuals and procedures (Zaheer and Manrakhan, 2001). Such knowledge can then be more easily transmitted and understood across geographical domains at a relatively low search cost (Makhija and Ganesh, 1997; Nonaka, 1994). The more easily a set of knowledge can be codified, the more easily it can be broken down into specific components to be articulated and transferred within the organization or among individuals without loss of meaning (Grant, 1996; Turner and Makhija, 2006). According to Schulz (2003, 446), the codification of knowledge reduces the employee effort required to manage knowledge. This, in turn, allows employees to "process new incoming knowledge faster because it facilitates and speeds up the establishment of linkages between old and new knowledge."

For example, a given process or template based on a prior project allows workers to know what type of knowledge they should seek out, and where they should go to look for that knowledge. 
Database queries allow workers to use multiple indexes and search functions, enabling them to localize and retrieve existing knowledge. For these reasons, Cantwell and Zhang (2009) have argued that information technology and templates have significantly decreased the costs of global search. Moreover, as Ambos and Ambos (2009) have found, technology-based coordination is much more efficient than personal interactions in the face of geographical distance.

\section{Information Technology Gaps}

Information technology undoubtedly provides a platform for efficiently transferring knowledge. However, the very qualities that make cross-boundary knowledge a source of competitive advantage also foster difficulties in the codification process. With its inability to convey causeand-effect relationships, codified knowledge can be difficult to transfer across borders (Cantwell and Mudambi, 2005; Jensen and Szulanski, 2004; Kostova and Roth, 2002). This causal ambiguity reduces actors' interest in codified knowledge as well as the value they ascribe to it (Helfat, 1994; Stuart and Podolny, 1996; Zaheer and Manrakhan, 2001). As a result, employees are likely to find little value in cross-border knowledge when it is transferred through information systems (Ambos and Ambos, 2009; March and Simon, 1958; Nelson and Winter, 1982; Rosenkopf and Nerkar, 2001).

This may explain the phenomenon by which an increase in geographical distance reduces the likelihood of cross-border investment, which in turn reduces the likelihood that a firm will be able to import valuable knowledge or efficiency techniques from one distant location to another (Beckerman, 1956; Beugelsdijk and Frijns, 2010; Disdier and Head, 2008; Kogut and Singh, 1988). Accordingly, Goodall and Roberts $(2003,1164)$ highlight that "the decay and loss due to distance is precisely the decay and loss of knowledge, relationships, and trust, which in turn 
undermine the ability to act at and over distance." Geographical distance thus acts as an obstacle to achieving contextual richness in knowledge networks and often prevents knowledge sharing among employees as well as among subsidiaries (Cantwell and Mudambi, 2005).

The specific difficulties associated with cross-border codified knowledge include unknown conditions, unknown social complexity, and difficulty in evaluating the value of the information (Cyert and March, 1992; Hansen and Lovas, 2004; Zaheer, 1995). In fact, Zaheer and Manrakhan (2001) note that regardless of how highly codified or how successfully embedded in information systems knowledge may be, firms are unlikely to utilize this knowledge when it must be retrieved from distant locations. This is likely attributable to the inability of employees to grasp the nuances of key relationships solely from documents. To address this issue, research on centers of excellence suggests firms might consider designating a centralized location where specific skills and technologies can be readily drawn upon to improve product performance and service (Rugman and Verbeke, 2008). In contrast, attempts to draw on information technology from distant locations may be saddled with unfamiliar elements that require greater investments in time and effort to overcome. These conditions create uncertainty in the processes surrounding knowledge transfer, which in turn may reduce the value employees ascribe to knowledge that is codified, but distant.

That said, when employees are more inclined to search for solutions locally rather than across countries and regions, the MNE may forfeit its advantage over local competitors. Indeed, an MNE's advantage may depend upon the extent to which employees are interested in and ascribe value to codified knowledge that allows them to draw upon ideas from distant locations (Ambos et al., 2006a; Kogut and Zander, 2003; Monteiro et al., 2008; Szulanski and Jensen, 2006). Some scholars have argued that knowledge in narrative form is the most likely to generate this interest and value. 


\section{Codified Narratives as a Bridge}

We understand the narrative genre of knowledge management as a novel form of organizational knowledge that combines longstanding methods of interpersonal knowledge transfer with the efficiency benefits of technology (Snowden, 1999a; Thomas, 1999). Narrative knowledge management has the potential to leverage technological advantages like immediate and global search, download and upload, while fostering the emotional connectivity necessary for people to actually enjoy, identify with, and fully understand the information being transferred.

For example, Bhardwaj and Monin $(2006,72)$ pointed out the need for "technology that would be able to effectively capture the multidimensional interplay of tacit knowledge with important subsystems of the organization." Likewise, Snowden (2002) argued that companies are developing innovative indexing techniques to capture narratives. With these advances, narratives can be efficiently codified and then offered to larger audiences. Linde (2001) discussed how archival systems such as databases and "lessons learned" programs are typically less effective than face-to-face interaction, but also identified how these systems can be made more effective in transferring knowledge across borders by focusing on specific design dimensions. These key design dimensions include an attention to translation across genres and cultures, the use of system administrators to help the codification process, and the ability of proactive administrators to get people to codify their stories.

Overall, much of this research focuses on effective ways to operationalize and to disseminate stories across borders (Bowman and Ambrosini, 2001; Jensen and Szulanski, 2007). While it is clear codified narrative forms of knowledge fill an important role in MNE knowledge 
transfer, it is less clear what impacts an individual actor's interest in and valuation of one narrative over another in the MNE.

So, which elements of a narrative approach are responsible for determining a user's interest in and valuation of knowledge? To answer this key question, we conducted a detailed case study of knowledge transfer within the International Finance Corporation of the World Bank Group, which is currently engaged in an organization-wide narrative codification initiative. Our research resulted in a unique, multi-pronged data collection that included the following: interviews with those sharing and using knowledge, analysis of the content of over 175 narratives using a wordby-word coding scheme, exploration of how efforts of senior management at IFC support the emergent system, and examination of the actual use and evaluations of each narrative. Our research objective was to understand which aspects of the knowledge in its narrative form generate user interest in and valuation of that knowledge. Drawing on two streams of research related to social cognition and contagion, we developed a theoretical model linking emotional content and frequency of use to interest in and valuation of each codified narrative.

\section{Emotion and Perceived Value}

Emotional information likely influences the extent to which users attribute value to knowledge within an MNE. Scholars have argued that managers who are able to identify, assess and control the emotions of others within an organization are more effective than their less emotionally intelligent peers (Goleman, 1995). We define emotion here as the affective aspect of consciousness, connoting the subjective, conscious experience or feeling that spurs individuals to action (or dissuades them from doing so). Emotion may be expressed through actions or words. Scholars have shown that emotion can be mapped by attending to states of mind such as pride, 
humility, disgust, frustration, hope, consciousness of human frailty, and other positive and negative mental states (Anderson and McMaster, 1982; Lehnert and Vine, 1987).

Recent studies of narrative and social cognition have suggested that emotion, manifested in words, is the primary mechanism by which individuals convey information about themselves. Conveying emotional content in narrative form not only helps readers connect to the storyteller, but also fosters connections to the information itself (Miall, 1988). Unlike business reports or other more analytical modes of writing, stories are intended to entertain, to excite interest and to arouse various emotional responses that assist in engagement with embedded information (Brewer and Lichtenstein, 1982). In fact, certain types of vocalized emotion that endear the reader to the storyteller or to the embedded information may increase the value a listener ascribes to that story.

Ultimately, the perceived value of narratives is likely attributable to the emotional content of the narrative. Conveying honest emotion and frankly chronicling actual missteps and weaknesses is particularly of interest to knowledge users, especially as compared to generating a fictitious, whitewashed and overly rosy account of relevant events. This is the case not only because truthful information is perceived as the most valuable, but also because honest narratives are likely to be perceived as providing a realistic template of what can and cannot be done with available knowledge. Audience members are most likely to trust a narrative when they feel its authors were trying to be sincere and free from pretense and deceit. This trust is further fostered by a display of emotion from the authors — where the storytellers convey what they genuinely feel or believe-thereby alleviating concerns about dishonesty or hypocrisy. (For example, one manager questioned if others "will be as candid as IFC staff have been about things that have gone wrong in their projects?") 
Narrative scholars would lead us to believe that a perfect story, in which everything goes as planned, is fundamentally flawed in its failure to mimic reality, which alienates audiences and makes them distrustful. People seek not only to learn from their peers' narratives, but also to feel connected and to be treated with forthrightness. Based on this research, we expect that certain uses of emotion in narratives might increase both users' interest in those narratives and the value users' attributed to them.

Hypothesis 1: More emotional narratives are perceived as more valuable by users of the knowledge.

\section{Contagion and Interest}

Actors within a firm, when making determinations about the relative importance of information, are likely to look to others for social cues. This process is one of contagion, in which the ideas perceived to be most interesting will spread quickly within the organization. The level of contagion is determined by frequency of interaction, formation of trust between actors, and the influence of one actor's interests on others. As Lawler and Yoon (1993, 1996, 1998) argued, actors who frequently associate are likely to forge mutual trust. This trust, in turn, makes actors more likely to rely upon each other to determine which information is of most interest. As Cross and Parker (2004) noted, actors who frequently interact are likely to look out for one another's interests. This practice of turning to others in an attempt to determine what is important is relied on most heavily in the case of ambiguous information whose value may be elusive (Weick, 1995; Weick and Roberts, 1993). 
Endorsement, whether formal or informal, constitutes a major element of marketing efforts for products seeking to acquire both buzz and legitimacy. Information endorsed by colleagues, then, will be considered particularly valuable. This value is heightened even further when the narrative is endorsed by the organization as a whole. Hence, we propose:

Hypothesis 2: Narratives endorsed by an organization will attract user interest.

Methods

Sample. To test these hypotheses, we conducted a detailed case analysis of the International Finance Corporation (IFC) of the World Bank Group. The IFC fosters sustainable economic growth in developing countries by generating private sector investment, mobilizing capital in the international financial markets, and providing advisory services to businesses and governments. The IFC helps companies create jobs, generate tax revenues, improve corporate governance and environmental performance, and contribute to local communities (IFC Corporate Relations, 2010). Actors within the IFC, then, have a constant need to learn about new and innovative practices to increase economic development and facilitate project success. While much of this occurs through direct learning-by-doing — communicating and working with local businesses and communitiesthe IFC must also manage the sharing of knowledge across its geographically diverse locations. Because the services the IFC provides are broad in scope, repurposing knowledge is often difficult, as is the process of matching existing knowledge stocks to the knowledge needs of the current project. Still, achieving effective knowledge transfer remains important, as it would allow the IFC to improve outcomes by importing information from past projects' failures and successes. As a 
result, the IFC has elected to codify and transfer general principles in the form of narratives, imbuing them with a broader application than more template-based knowledge stocks.

SmartLessons. Recognizing the need to better leverage knowledge across borders, the IFC implemented a narrative knowledge system that allows people to connect to knowledge in a way that fosters human connection. A pioneer in this approach, the organization sought to combine globally efficient information technology and multimedia with locally effective narratives written by project leaders in the field. This effort aimed to provide on-demand narratives to employees in every part of the organization, by offering a dynamic online repository of participant-authored narratives that emerge directly from the field projects.

The IFC has named this grassroots program "SmartLessons." The narratives are written by and for project leaders, and the program is completely voluntary, with participation encouraged by senior management. Ultimately, it has become very successful within the IFC. As the former director of the IFC's Infrastructure Advisory Department said, "Sharing experiences and lessons while they're still alive helps our teams contribute to and benefit from being part of a worldwide professional family and enables us to provide clients with what they expect: advice based on deep, up-to-date, global experience."

As advisory service activities within the IFC grew and expanded into more markets, the difficulty of sharing knowledge across offices increasingly impeded the organization's ability to offer interesting and valuable knowledge about new, innovative services (Nahapietand and Ghoshal, 1998). However, employees still needed to engage in this sort of sharing so they could access the knowledge principles embedded in narratives and better understand how to approach current problems. As a result, the IFC developed an innovative solution that could potentially solve 
concerns about finding interesting and valuable information quickly and with reduced effort. In the words of one analyst, "There are a lot of quite successful initiatives-LISTSERVs, communities of practice, etc. - and they all have an important role to play. However, we felt that we could supplement these initiatives by filling an important KM [knowledge management] niche." This SmartLesson niche would simultaneously utilize meaningful connectivity through narratives and on-demand access to information systems.

In an effort to fill this niche, the general managers of the IFC's regional business advisory services offices convened for a brainstorming meeting. One idea was to develop a "Lessons Learned" brochure. This would be a "traditional," top-down technical publication, developed in the organization's headquarters. Almost simultaneously, another idea was put forward, one that would enable people on the ground - those who actually do the projects - to share lessons learned in an uploadable, IT-based format. The second, grassroots approach generated the most enthusiastic support, so this latter effort was launched.

To enable these grassroots stories to spark interest and provide value for users, the IFC managers decided they needed to adopt a more contextualized approach that allowed readers to connect with the author(s). Stories could help potential knowledge recipients connect with the human aspect of an individual's learning experience, providing a comprehensible and compelling format for advice. The managers considered crafting these stories by employing multimedia, such as pictures, graphs, and hyperlinks. They also acknowledged the importance of internal marketing to catch people's interest and create a buzz around the program. Finally, they established that the lessons needed to be principle-based, short, and narrative in structure. By providing these wellmarketed, highly contextualized narratives in an easily searchable and quickly uploadable format, the IFC hoped to generate interest in the knowledge. 
Our study is unique for its focused analysis on the knowledge itself, rather than on the users of the knowledge. In this regard, we have been able to examine which specific elements of a narrative make it perceived as more valuable and interesting. We note here that, like most large, globally-dispersed, knowledge-intensive organizations, the IFC has developed numerous knowledge management resources and processes. For purposes of this study, we have focused exclusively on the use of SmartLessons.

The SmartLessons website originated in November 2005 as a repository for grassroots knowledge sharing. Each SmartLesson narrative consists of a simple, three- to four-page account of an individual or group experience providing development assistance in an emerging market. Most lessons are written by people in the field, by their own initiative and in their own style. The sole instruction they receive comes from a short guide on formatting, a desk editor provides a light edit for coherence, and then the stories are posted directly to the website. Most authorsencouraged by the simplicity of a process that is light on bureaucracy — take the time to codify their information simply because they want to share their efforts with others. Narratives come from all regions and may be authored either individually or by a group. They are fully searchable by topic, by author or by keyword. As one IFC member stated, "The SmartLessons program is the first time I have felt empowered as a member of staff to write a 'no holds barred' account of lessons I learned implementing an advisory services project. This type of 'grassroots' conversation and exchange of ideas between peers is a refreshingly new approach to the way lessons of experience are shared in the organization." (See Figure 1 below, for an example of a SmartLesson).

Figure 1: Narrative Example 


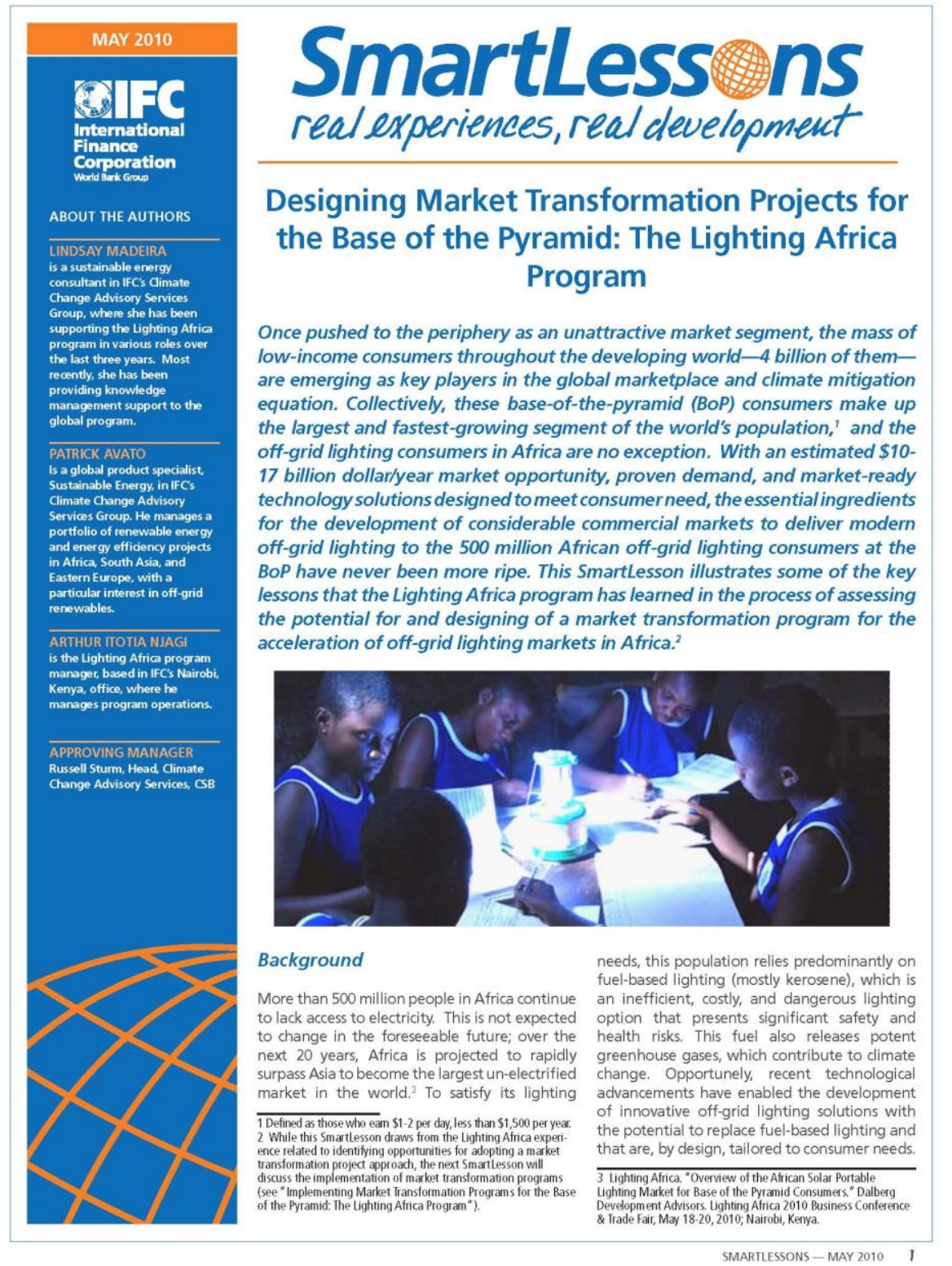

We drew on interviews with IFC employees and managers to investigate which factors drove actors' interest in, and use of, the SmartLesson narratives. Strikingly, we found that SmartLessons had near-universal application and were often enjoyed by their users ("enjoyed," it should be noted, is a word not often associated with knowledge management). Narratives inject a human element into systems for organizing ideas and preserving individual memory. Knowledge gleaned from these systems is more likely to be utilized by organizational actors, who are able to 
draw on information in an easily accessible format (Pollock and Rindova, 2003). We sought to empirically test the specific effects of this human element on the use and perceived value of each SmartLesson, assessing the level of emotional intensity of, as well as employees' interest in and valuation of, each of the various SmartLesson narratives.

\section{Data Collection}

Before examining the contents of the documents, we conducted 64 semi-structured interviews to help us understand how knowledge was perceived and used by individuals within the IFC. Interviews lasted between 30 to 120 minutes, and were conducted on-site in the following locations: Peru, Bolivia, South Africa, Indonesia, China, Vietnam, Egypt, and the IFC headquarters in Washington, D.C. Of the 64 total interviews, 18 were conducted in IFC headquarters and 46 in foreign emerging markets. When interviewing managers, we asked them not only about their employees' interactions with narratives, but also about how they perceived and used the narratives for themselves. (Most managers we interviewed were heavily invested in utilizing narratives to help them with their own projects.) After these interviews were conducted, we obtained the complete list of the first 175 SmartLesson narratives, along with their hit count and user ratings. We then analyzed each narrative using the Atlas.ti content analysis program.

\section{Data Analysis}

Each of this study's two authors independently coded two top-rated narratives and two bottomrated narratives, and then arrived at a consensus on the necessary categories for coding the narratives. The authors then trained an independent coder to code all 175 SmartLesson narratives, either word-by-word or phrase-by-phrase, based on four key emotive components of each 
narrative - simply put, when the writer of a narrative used terms associated with "success," "fault," "hope," or "frustration."

First, a narrative was coded as "success" when the authors described or claimed "success," "prior success," "achieve(ment)," "positive results," or “meeting objectives." Five percent of the narratives had no "success," eleven percent contained only one "success," and nine percent claimed two or more "successes." The mean narrative contained 7.01 claims of success, with a minimum of 0 and a maximum of 26. Second, a narrative was coded for "fault" when the authors of the narrative attributed fault either to themselves or to others. We coded "fault" for words like "fault," "mistake," "error," and "fail." The average narrative contained 0.72 attributions of fault with a minimum of 0 and a maximum of 14 . Third, we coded "hope" when the authors indicated "hope," "encouraging," "await," or "believe." The average narrative contained 0.09 expressions of hope, with a minimum of 0 and a maximum of 3 . Fourth, we coded "frustration" when narratives contained expressions such as "frustrated," "thwarted," “all for naught," "stall," "hampered," or "limited." On average, expressions of frustration were contained in 0.73 narratives, with a minimum of 0 and a maximum of 14.

Additionally, we coded stories based on the level of multimedia included in the narrative. Knowledge communicated in a multimodal nature provides more cues to users and helps them to understand relevant information. For instance, one interviewee said, "knowledge is much more accessible and useful when you can get a richer understanding of it." We assessed the multimedia aspects of narratives by examining the extent to which the narratives included media other than text. We coded each narrative's use of pictures, tables, graphs, charts, hyperlinks and other media. On average, each narrative contained 1.77 pictures, 0.24 tables, and 0.56 other media. 


\section{Dependent Variables}

Value. In June 2006, the IFC instituted a voluntary ranking system for the SmartLessons, allowing users to rate the perceived value of a story; with each story, users have the option of rating it on a five-star rating system (with a rating of 1 star representing low value, and a rating of 5 stars representing high value). Users also have the option of offering peer evaluations, by entering comments alongside the rating in order to help others locate "more useful" stories. One manager said, "The rankings really help identify value in the knowledge. It is so helpful to rely on others to help determine which stories are most valuable." Therefore, this study measures the perceived value of a story using a five-point scale (with 1 representing no value, and 5 representing very valuable). Through examining ratings by multiple viewers of the same story, we obtained the average rating for each story and used that average to determine the value attributed to it within the IFC.

Interest. In addition to the value attributed to each narrative, we assessed readers' interest in a given narrative by calculating the number of times a narrative was accessed by a first-time user. Examining unique visits to each narrative helped indicate the nature of the interest in each narrative. (See Table 1 below for descriptive ratings by geography, gender and number of authors.)

Table 1. Narratives by geography, author, gender, and author number

\begin{tabular}{|c|c|c|c|c|}
\hline Location of project & $\begin{array}{l}\text { Count } \\
\text { article }\end{array}$ & $\begin{array}{l}\text { Number of } \\
\text { hits }\end{array}$ & $\begin{array}{l}\text { Average } \\
\text { rating }\end{array}$ & Std. dev. \\
\hline Central \& Eastern Europe & 19 & 1293 & 4.00 & 0.72 \\
\hline East Asia \& Pacific & 25 & 849 & 3.17 & 1.25 \\
\hline Latin America \& Caribbean & 23 & 886 & 3.71 & 1.33 \\
\hline Middle East \& North Africa & 18 & 1106 & 3.89 & 0.94 \\
\hline South Asia & 15 & 855 & 4.09 & 0.59 \\
\hline Southern Europe and Central Asia & 23 & 990 & 3.53 & 1.09 \\
\hline Sub-Saharan Africa & 20 & 999 & 4.10 & 1.28 \\
\hline
\end{tabular}




\begin{tabular}{|lllll|}
\hline Unknown & 32 & 1188 & 3.57 & 1.14 \\
Total & 175 & 8166 & 3.75 & 1.09 \\
\hline
\end{tabular}

\begin{tabular}{|lllll|}
\hline Gender of author(s) & $\begin{array}{l}\text { Count } \\
\text { article }\end{array}$ & $\begin{array}{l}\text { of } \\
\text { hits }\end{array}$ & $\begin{array}{l}\text { Average } \\
\text { rating }\end{array}$ & Std. dev. \\
Male & 59 & 2688 & 3.89 & 1.16 \\
Female & 65 & 3186 & 3.80 & 1.09 \\
Mixed gender & 51 & 2264 & 3.43 & 0.98 \\
Total & 175 & 8166 & 3.75 & 1.09 \\
\hline
\end{tabular}

\begin{tabular}{|lllll|}
\hline Number of authors & $\begin{array}{l}\text { Count } \\
\text { article }\end{array}$ & $\begin{array}{l}\text { Number of } \\
\text { hits }\end{array}$ & $\begin{array}{l}\text { Average } \\
\text { rating }\end{array}$ & Std. dev. \\
1 & 98 & 4535 & 3.77 & 1.10 \\
2 & 36 & 1821 & 3.90 & 0.88 \\
3 & 14 & 989 & 4.27 & 0.80 \\
4 & 8 & 334 & 2.49 & 1.03 \\
5 & 2 & 50 & 3.50 & 0.70 \\
6 or more & 17 & 426 & 3.33 & 2.08 \\
Total & 175 & 8166 & 3.75 & 1.09 \\
\hline
\end{tabular}

\section{Independent Variables}

Emotion. Because we predicted that the interest in and value attributed to narrative knowledge is tied to its emotional content, we coded each narrative for certain emotions. Based on the data collection method described above, we measured the presence of the following states of mind: success, fault, hope, or frustration.

Success was evidenced by expressions of excitement about a task that worked well. Expressions of success are "event-related," and success is associated with the positive spectrum of emotion. Expressions of success in narrative form can help to spur feelings of triumph and pleasure. Authors express success by using phrases like "this worked as planned" or "we achieved some success pleasing our client." Fault was evidenced by an admission of error in which the authors admitted problems and imperfections (e.g., "we fell behind schedule" or "we missed objectives"). As a negative emotion, fault signifies regret or disappointment. Fault is also "event- 
related" and can be manifested by admitting error. Hope, on the other hand, represents a future appraisal offering encouragement as an emotion. Hope was evidenced by sentences in which the authors conveyed to the reader that accomplishing a task was possible, easy, or both. Finally, frustration was evidenced by sentences conveying key words that suggested frustration with a project's progress. Frustration is also an "event-related" emotion associated with the negative spectrum. In all, the average narrative included 18.08 emotional elements, with a standard deviation of 2.83. (See Table 2 for mean, correlations and summary statistics.) 
Table 2: Descriptive Statistics and Correlations

\begin{tabular}{|c|c|c|c|c|c|c|c|c|c|c|c|c|c|c|c|c|c|}
\hline & & Ave. & $\begin{array}{l}\text { Std. } \\
\text { dev. }\end{array}$ & Min. & Max. & 1 & 2 & 3 & 4 & 5 & 6 & 7 & 8 & 9 & 10 & 11 & 12 \\
\hline 1 & Interest & 43.97 & 32.77 & 1 & 213 & & & & & & & & & & & & \\
\hline 2 & Ratings & 3.81 & 1.03 & 1 & 5 & 0.07 & & & & & & & & & & & \\
\hline 3 & Picture count & 1.49 & 1.62 & 0 & 7 & 0.07 & 0.15 & & & & & & & & & & \\
\hline 4 & Table count & 0.34 & 0.73 & 0 & 4 & -0.10 & -0.01 & -0.13 & & & & & & & & & \\
\hline 5 & Other count & 0.51 & 1.07 & 0 & 7 & 0.06 & 0.10 & -0.09 & 0.07 & & & & & & & & \\
\hline 6 & Endorsement & 0.22 & 0.43 & 0 & 2 & 0.42 & 0.06 & 0.02 & -0.11 & -0.06 & & & & & & & \\
\hline 7 & Winner & 0.14 & 0.35 & 0 & 1 & 0.28 & -0.06 & 0.20 & 0.03 & 0.02 & 0.14 & & & & & & \\
\hline 8 & Runner-up & 0.18 & 0.40 & 0 & 2 & 0.12 & -0.08 & 0.08 & 0.03 & 0.06 & 0.04 & -0.02 & & & & & \\
\hline 9 & Round 1 & 4.30 & 1.15 & 1 & 5 & 0.25 & 0.68 & 0.06 & -0.05 & 0.12 & 0.04 & -0.02 & 0.07 & & & & \\
\hline 10 & Round 2 & 2.38 & 2.32 & 0 & 5 & 0.33 & 0.04 & -0.01 & -0.01 & 0.11 & 0.23 & 0.05 & 0.02 & 0.21 & & & \\
\hline 11 & Round 3 & 1.57 & 2.20 & 0 & 5 & 0.23 & -0.16 & 0.01 & 0.01 & 0.29 & 0.07 & 0.00 & 0.08 & 0.17 & 0.56 & & \\
\hline 12 & Round 4 & 1.09 & 1.89 & 0 & 5 & 0.26 & -0.12 & -0.09 & -0.01 & 0.30 & 0.05 & 0.05 & 0.06 & 0.21 & 0.46 & 0.70 & \\
\hline 13 & Frustration & 0.73 & 1.87 & 0 & 14 & -0.07 & 0.03 & 0.09 & 0.00 & -0.06 & -0.09 & 0.02 & 0.10 & 0.02 & -0.09 & -0.11 & -0.14 \\
\hline 14 & Hope & 0.10 & 0.40 & 0 & 3 & -0.03 & -0.13 & 0.08 & 0.28 & 0.04 & 0.01 & 0.19 & 0.00 & -0.11 & 0.16 & 0.16 & -0.05 \\
\hline 15 & Fault & 0.21 & 0.62 & 0 & 4 & 0.23 & 0.07 & -0.07 & -0.02 & 0.14 & 0.05 & 0.13 & 0.23 & 0.02 & -0.15 & -0.18 & -0.13 \\
\hline 16 & Success & 7.01 & 5.63 & 0 & 26 & 0.12 & 0.11 & -0.05 & 0.04 & -0.05 & 0.08 & 0.09 & -0.06 & -0.08 & -0.03 & 0.00 & -0.04 \\
\hline 17 & Std. dev. of ratings & 0.94 & 1.04 & 0 & 2.83 & 0.11 & -0.41 & 0.06 & -0.06 & 0.05 & 0.03 & 0.14 & 0.13 & 0.11 & 0.50 & 0.57 & 0.45 \\
\hline 18 & Number of authors & 1.61 & 0.94 & 1 & 5 & 0.05 & -0.17 & 0.16 & -0.03 & 0.05 & 0.00 & 0.05 & -0.03 & -0.07 & 0.05 & 0.11 & 0.08 \\
\hline 19 & Number of themes & 1.47 & 0.60 & 1 & 3 & 0.13 & -0.01 & 0.07 & -0.09 & 0.07 & 0.07 & 0.10 & -0.14 & -0.09 & 0.02 & -0.16 & -0.16 \\
\hline 20 & Number of subthemes & 2.23 & 5.74 & 1 & 66 & 0.07 & -0.03 & 0.00 & -0.05 & -0.04 & 0.11 & -0.03 & 0.03 & -0.02 & 0.13 & 0.18 & 0.01 \\
\hline 21 & Adjectives & 32.98 & 16.58 & 0 & 100 & -0.08 & 0.01 & -0.12 & 0.17 & -0.06 & -0.03 & 0.00 & -0.06 & -0.02 & -0.11 & -0.10 & -0.02 \\
\hline 22 & Adverbs & 15.56 & 6.51 & 0 & 39 & 0.10 & -0.06 & -0.01 & 0.18 & -0.08 & -0.04 & 0.03 & -0.02 & 0.10 & 0.06 & 0.01 & -0.02 \\
\hline 23 & Gender of author(s) & 0.98 & 1.06 & 0 & 3 & 0.06 & -0.10 & 0.08 & -0.10 & 0.02 & 0.08 & -0.03 & 0.01 & 0.05 & 0.27 & 0.27 & 0.29 \\
\hline 24 & Author count & 3.74 & 6.14 & 0 & 46 & 0.36 & -0.02 & -0.06 & -0.03 & 0.28 & 0.21 & -0.02 & 0.18 & 0.22 & 0.53 & 0.67 & 0.74 \\
\hline 25 & Access & 0.20 & 0.40 & 0 & 1 & -0.08 & -0.18 & -0.01 & -0.01 & -0.06 & -0.05 & -0.02 & -0.04 & -0.20 & -0.07 & -0.05 & -0.14 \\
\hline 26 & Environment & 0.20 & 0.40 & 0 & 1 & -0.12 & 0.12 & -0.07 & -0.03 & 0.03 & -0.20 & 0.01 & -0.05 & 0.13 & -0.01 & 0.04 & 0.06 \\
\hline 27 & Operations & 0.14 & 0.34 & 0 & 1 & 0.17 & 0.01 & 0.13 & -0.09 & -0.05 & 0.21 & 0.15 & -0.10 & 0.10 & 0.02 & 0.01 & 0.02 \\
\hline 28 & Results & 0.10 & 0.31 & 0 & 1 & 0.11 & -0.04 & -0.22 & 0.24 & 0.06 & 0.01 & -0.08 & 0.04 & -0.10 & 0.07 & 0.05 & 0.13 \\
\hline
\end{tabular}




\begin{tabular}{|c|c|c|c|c|c|c|c|c|c|c|c|c|c|c|c|c|c|}
\hline & & 13 & 14 & 15 & 16 & 17 & 18 & 19 & 20 & 21 & 22 & 23 & 24 & 25 & 26 & 27 & 28 \\
\hline 14 & Hope & -0.07 & & & & & & & & & & & & & & & \\
\hline 15 & Fault & 0.05 & -0.06 & & & & & & & & & & & & & & \\
\hline 16 & Success & -0.15 & -0.06 & -0.09 & & & & & & & & & & & & & \\
\hline 17 & Std. dev. of ratings & -0.03 & 0.18 & -0.06 & -0.07 & & & & & & & & & & & & \\
\hline 18 & Number of authors & -0.01 & -0.01 & 0.00 & -0.05 & 0.21 & & & & & & & & & & & \\
\hline 19 & Number of themes & -0.11 & 0.01 & 0.08 & 0.05 & -0.02 & 0.07 & & & & & & & & & & \\
\hline 20 & Number of subthemes & 0.03 & -0.02 & -0.02 & 0.06 & 0.12 & -0.05 & 0.22 & & & & & & & & & \\
\hline 21 & Adjectives & 0.07 & -0.06 & 0.03 & 0.03 & 0.01 & -0.09 & 0.00 & 0.29 & & & & & & & & \\
\hline 22 & Adverbs & 0.00 & 0.00 & 0.08 & 0.10 & 0.08 & -0.04 & 0.04 & 0.15 & 0.41 & & & & & & & \\
\hline 23 & Gender of author(s) & 0.04 & -0.06 & -0.05 & -0.07 & 0.30 & 0.49 & 0.05 & 0.02 & -0.11 & -0.02 & & & & & & \\
\hline 24 & Author count & -0.12 & 0.02 & -0.03 & -0.09 & 0.35 & 0.06 & -0.01 & 0.06 & -0.08 & 0.01 & 0.25 & & & & & \\
\hline 25 & Access & -0.04 & -0.08 & -0.06 & 0.02 & 0.07 & 0.07 & -0.01 & 0.11 & 0.00 & 0.00 & -0.02 & -0.08 & & & & \\
\hline 26 & Environment & 0.03 & 0.06 & -0.10 & 0.07 & 0.09 & -0.10 & -0.11 & -0.03 & 0.03 & 0.04 & -0.04 & -0.03 & -0.25 & & & \\
\hline 27 & Operations & -0.12 & 0.08 & -0.02 & -0.05 & 0.08 & 0.03 & 0.14 & -0.03 & -0.10 & -0.02 & -0.05 & 0.00 & -0.20 & -0.20 & & \\
\hline 28 & Results & -0.02 & -0.09 & 0.15 & 0.07 & -0.10 & 0.03 & 0.00 & -0.04 & 0.13 & 0.01 & 0.01 & 0.36 & -0.17 & -0.17 & -0.14 & \\
\hline 29 & Value added & 0.17 & 0.00 & 0.07 & -0.03 & -0.09 & 0.02 & -0.14 & 0.00 & 0.05 & 0.01 & 0.08 & -0.03 & -0.29 & -0.29 & -0.23 & -0.20 \\
\hline
\end{tabular}

Correlations $>.14$ are significant at $\mathrm{p}=.05$ 
Organizational Endorsement. We also assessed organizational factors external to the story, including internal emails and other marketing efforts, as they may have influenced the perceived value and frequency of access of narrative knowledge. Each week, the administrators of the SmartLesson system selected up to three articles to feature in an internal email sent to all employees. These internal marketing efforts included a brief summary of the selected narrative and a hyperlink to access the full story. Examining internal promotion of narratives was critical, as organizational endorsements may increase or decrease the interest in and value attributed to a narrative. In short, knowledge sanctioned by the organization may be perceived as relatively more valuable.

\section{Control Variables}

Authors may submit narratives at any time, with the narratives periodically collected in "rounds" of knowledge sharing that encompassed 3 to 6 months of submission. The authors' contribution and use of narratives does not impact their job performance evaluations. Instead, employees who submit a narrative are given a nominal monetary incentive for participation, and are eligible to earn prizes if their narrative is selected as one of the top three narratives. For each round of submissions, a panel of volunteer judges evaluates the narratives published in that round, and selects three narratives as winners and three as runners-up. The winning authors are awarded a few hundred dollars for their efforts. At the time this study was conducted, the firm had engaged in five rounds of narrative collection. Employees continue to have only minimal incentives to submit narratives, and the repository is not yet comprehensive, with much knowledge that might be helpful still absent from the site. Still, the number of narratives is increasing at a steady rate. 
This study required us to control for a number of key variables. We used dummy variables to control for the time period in which the story was collected. Our relevant comparison period was Period 5. We controlled for the standard deviation of the ratings, as a wide deviation in ratings could indicate a polarization of opinion and highlight more controversial knowledge or projects. We calculated the number of themes and subthemes in the story to control for the presence of knowledge that may be applicable in a particularly broad context, and therefore more highly sought-after. We controlled for the robustness of description in each story by attending to the number of adjectives and adverbs used. We controlled for the gender of the author (or, the predominant gender of the authors, in the case of a group-authored narrative). If the authors' genders were split equally, then they were categorized as "mixed". We controlled for the number of ratings for each narrative. Finally, we accounted for differences in the themes of the narratives by including controls for the following six different subjects: access to finance (access), business enabling environment (environment), managing operations (operations), results management (results), value addition to firms (value addition), and other (other).

\section{Results}

We conducted an ordinary least squares (OLS) regression with robust standard errors to examine how these various emotional and contextual factors relate to employee interest in and valuation of knowledge. 
Table 3. OLS regression results ${ }^{\mathrm{a}}$

\begin{tabular}{|c|c|c|}
\hline & Model I & Model II \\
\hline & Value & Interest \\
\hline \multicolumn{3}{|l|}{ Emotion } \\
\hline \multirow[t]{2}{*}{ Frustration } & -0.015 & -0.386 \\
\hline & $(1.06)$ & $(0.20)$ \\
\hline \multirow[t]{2}{*}{ Hope } & $-0.227 * * *$ & -1.495 \\
\hline & $(3.65)$ & $(0.18)$ \\
\hline \multirow[t]{2}{*}{ Fault } & $0.069 * *$ & 3.585 \\
\hline & $(2.04)$ & $(0.79)$ \\
\hline \multirow[t]{2}{*}{ Success } & 0.003 & -0.10 \\
\hline & $(0.61)$ & $(0.16)$ \\
\hline \multicolumn{3}{|l|}{ Organizational endorsement } \\
\hline \multirow[t]{2}{*}{ Round winner } & $-0.115^{*}$ & $23.751 * * *$ \\
\hline & $(1.89)$ & $(2.98)$ \\
\hline \multirow[t]{2}{*}{ Round runner up } & -0.041 & $9.879 *$ \\
\hline & $(0.94)$ & $(1.72)$ \\
\hline \multirow[t]{2}{*}{ Marketed } & -0.06 & $19.54 * * *$ \\
\hline & $(0.04)$ & $(5.69)$ \\
\hline \multicolumn{3}{|l|}{ Controls } \\
\hline \multirow[t]{2}{*}{ Picture count } & 0.011 & 1.501 \\
\hline & $(0.89)$ & $(0.90)$ \\
\hline \multirow[t]{2}{*}{ Table count } & -0.031 & -5.178 \\
\hline & $(0.81)$ & $(1.04)$ \\
\hline \multirow[t]{2}{*}{ Media count } & -0.01 & 1.925 \\
\hline & $(0.48)$ & $(0.76)$ \\
\hline \multirow[t]{2}{*}{ Round 1} & $0.995 * *$ & $13.955^{*}$ \\
\hline & $(59.28)$ & $(2.57)$ \\
\hline \multirow[t]{2}{*}{ Round 2} & -0.014 & 2.368 \\
\hline & $(1.18)$ & $(1.76)$ \\
\hline \multirow[t]{2}{*}{ Round 3} & $0.042 * * *$ & 3.065 \\
\hline & $(2.93)$ & $(1.59)$ \\
\hline \multirow[t]{2}{*}{ Round 4} & $-0.099 * * *$ & 0.338 \\
\hline & $(4.56)$ & $(0.18)$ \\
\hline \multirow[t]{2}{*}{ Std. dev. of ratings } & $-0.742 * * *$ & $-14.009 * *$ \\
\hline & (32.15) & $(2.77)$ \\
\hline \multirow[t]{2}{*}{ Number of authors } & 0.009 & 0.02 \\
\hline & $(0.44)$ & $(0.01)$ \\
\hline \multirow[t]{2}{*}{ Number of themes } & -0.044 & 5.078 \\
\hline & $(1.11)$ & $(0.98)$ \\
\hline \multirow[t]{2}{*}{ Number of subthemes } & 0.007 & -1.258 \\
\hline & $(0.30)$ & $(0.43)$ \\
\hline \multirow[t]{2}{*}{ Adjectives } & 0.001 & -0.151 \\
\hline & $(0.51)$ & $(0.88)$ \\
\hline Adverbs & 0.001 & $1.555^{* *}$ \\
\hline
\end{tabular}




\begin{tabular}{|c|c|c|}
\hline & $(0.20)$ & $(3.91)$ \\
\hline \multirow[t]{2}{*}{ Gender of author(s) } & 0.019 & -3.224 \\
\hline & $(1.00)$ & $(1.30)$ \\
\hline \multirow[t]{2}{*}{ Number of ratings } & 0.029 & 0.657 \\
\hline & $(1.89)$ & $(0.92)$ \\
\hline \multirow[t]{2}{*}{ Access } & -0.038 & -7.512 \\
\hline & $(0.61)$ & $(0.92)$ \\
\hline \multirow[t]{2}{*}{ Environment } & -0.065 & 5.692 \\
\hline & $(0.85)$ & $(0.57)$ \\
\hline \multirow[t]{2}{*}{ Operations } & 0.021 & -11.324 \\
\hline & $(0.32)$ & $(1.32)$ \\
\hline \multirow[t]{2}{*}{ Results } & $0.643 * * *$ & -0.045 \\
\hline & $(4.92)$ & $(0.00)$ \\
\hline \multirow[t]{2}{*}{ Value addition } & -0.049 & -11.252 \\
\hline & $(0.73)$ & $(1.27)$ \\
\hline \multirow[t]{2}{*}{ Africa } & -0.046 & 8.427 \\
\hline & $(0.07)$ & $(8.11)$ \\
\hline \multirow[t]{2}{*}{ Europe } & -0.055 & -3.728 \\
\hline & $(0.07)$ & $(8.18)$ \\
\hline \multirow[t]{2}{*}{ Asia } & -0.031 & $(-2.187$ \\
\hline & $(0.07)$ & (7.34) \\
\hline \multirow[t]{2}{*}{ Average rating } & & $-14.866 * *$ \\
\hline & & $(2.38)$ \\
\hline \multirow[t]{2}{*}{ Constant } & 0.133 & 20.921 \\
\hline & $(1.08)$ & $(1.24)$ \\
\hline Observations & 76 & 77 \\
\hline R-squared & 0.89 & 0.75 \\
\hline
\end{tabular}

With Hypothesis 1, we suggested that emotional content would raise the value attributed to a given narrative. Model 1 in Table 3 indicates that admissions of fault are associated with higher evaluations of the story, supporting our Hypothesis 1. Admissions of error are also important, not only because they interject a human element into the story, but also because they can inform audiences about how to succeed in subsequent similar projects. Too often, employees cut corners or embellish when codifying knowledge in order to project an air of confidence and capability, in the hope of achieving a high performance rating based on that perception. Admitting error signals that the larger story being told is truthful, rather than exaggerated. In a larger sense, 
admissions of error imbue the information at hand with humanity, by acknowledging the fallibility of the author. We found that stories with admissions of error were nearly $125 \%$ more likely to be rated as particularly valuable. On the other hand, those stories containing emotional language associated with hope were significantly less likely to be perceived as valuable. Thus, our Hypothesis 1 received mixed support.

Model 2 in Table 3 suggests that organizational endorsement, in the forms organizational prizes as well as internal marketing efforts, spurred employee interest in the knowledge embedded within the narratives. Stories receiving organizational accolades, such as awards, are likely to spark initial interest among employees. As one project manager stated, "When I first heard that IFC was giving prizes or awards to staff for sharing their project experiences, I didn't think this was an idea with 'legs'-I mean, who would have the time to write? But I've watched the SmartLessons program go from strength to strength, and the numbers of lessons increased from only 8 a year ago to nearly 150 today. I checked the other day, and one lesson with an interesting title, 'Changing Tires on a Moving Car,' had nearly 500 downloads. Plus, there are videos of staff members talking about lessons from Aceh [Indonesia] — cool stuff.” This finding supports our Hypothesis 2, which posited that organizational endorsement would be positively correlated with employee interest.

Moreover, effective marketing efforts included a weekly SmartLesson in IFC's daily Newsflash feature, which highlighted a story in a short email message, as well as a feature entitled "Real People, Real Stories," which highlighted the authors of the stories (complete with author photos) and provided a link for users to access the story. The "Real People, Real Stories" feature was notable for its witty appeal, as is evident in the following two stories:

Tom's [a pseudonym] original career plan was "to be a ski instructor in winter and a dive master in summer," so that he could "hang out in cool bars and talk to girls all 
day." His parents soon squashed that idea and Tom became a banker instead: "I thought I'd be rich, surrounded by beautiful women and sports cars." But once he'd made it to the top, Tom became frustrated: “I felt like it didn't matter how good I was or what I did, the industry would often seem to be driven by greed and I couldn't change that." So Tom decided to work for IFC, not—-he insists—-to improve the world, although he grudgingly admits to the "occasional warm feeling" when a project changes peoples' lives for the better. And, Tom does still carry around his diving certificate wherever he goes, ever hopeful of breaking into his original career choice. Read Tom's SmartLesson by Clicking Here.

Georgia works on the evaluation and monitoring of IFC projects in Southeast Europe, but before the war in the former Yugoslavia she was a mechanical engineer. It was a job she loved, although designing machinery—rather than building it—was her strength. When it comes to actually handling anything technical Georgia admits she tends to break it: “Even my daughter says 'Mum, you are very clever, but just don't touch anything.' I guess I'm not so good with my hands." But Georgia has retained her passion for all machines, especially motorbikes, and almost every weekend the whole family zooms off to explore the Bosnian countryside. And when her motorbike breaks down, Georgia gives instructions, even draws diagrams of how it could be fixed, but she gets someone else to repair it. Read Georgia's SmartLesson here.

In much the same way an entertainment magazine might attract attention, SmartLessons provided a way for professionals, coming from many different countries and often overburdened 
with technical demands, to briefly come together and share a little bit about who they are. In the words of one manager, "SmartLessons offers a chance for your regular operations analyst in N'Djamena [Chad] to bond and share ideas with a project leader in Dhaka [Bangladesh] without having to move across continents or even pick up the phone." This internal marketing effort, which aimed at providing a personal connection between knowledge source and recipient, dramatically increased interest in the story. Narratives marketed by the organization were nearly twice (1.79 times) as likely to be initially viewed as narratives that did not.

\section{Discussion}

The SmartLessons program has been successful at generating interest in and increasing value attributed to cross-border knowledge. Unlike traditional narratives, this program does not require direct interaction with others, and so it decreases the need to coordinate schedules and work programs. The program is also successful because the narratives generated, although codified, are nonetheless emotionally rich and have a high perceived value to users. Moreover, by utilizing both formal and informal contagion-based marketing approaches, the organization increases user interest in the narrative knowledge. Additionally, SmartLessons offers a common platform for simple document upload and download, creating both a common location (on the firm intranet) and a common structure (quick and interesting stories from people in the relevant field).

Still, it is important to remember that even though employees are utilizing the narratives at a phenomenal rate, whether the narratives are actually effective at transferring knowledge remains an open question. Our results in this paper explore which factors increased interest in stories, as well as which factors led users and experts within the company to evaluate stories as "useful." We found that marketing efforts within the firm, coupled with organizational accolades, spurred 
employee interest in a given story. A high emotional content, on the other hand, was likely to both increase (in the case of fault) and decrease (in the case of hope) perceived value.

\section{Implications}

Our work has several implications for theory and practice. First, narratives provide an effective means for organizations to transfer organizational knowledge. Unlike other forms of codified knowledge, narratives stir emotions in the knowledge recipients, thereby increasing their interest in the knowledge as well as the value they attribute to it. Many firms currently lack formal systems to codify narratives internally, an obstacle that may limit the firm's ability to transfer knowledge. Our research indicates that organizations would benefit from creating knowledge systems that codify narratives.

Second, our research is one of the first to link the perceived value of information to the emotional component of the narrative. Organizations keen to transfer knowledge should consider means of codifying the emotional elements of knowledge in addition to technical aspects. By focusing on these emotional components, firms can increase the likelihood of knowledge utilization across the organization.

Third, our research indicates that organizational leaders can directly increase the use of narratives by engaging in marketing efforts, which both increase interest in narratives and increase their use. Although, it should be noted here that these marketing actions do not directly impact the perceived value of the narrative, which remains instead tied to the presence of emotional content.

Our results suggest several avenues for future research. For instance, researchers might take up the question of how specifically emotion leads to an increase in perceived value. What mechanisms are at work? Why do some types of emotion lead to perceived value while others do 
not? Does the presence of emotional content increase trust? Does it make the narrative more robust and detailed? In addition, researchers might explore circumstances in which employee interest and perceived value are both positively and negatively correlated. Which aspects of narratives drive both employee interest and perceived value, and which aspects drive one but not the other? Answering these questions could lead to a better understanding of the relative importance of certain facets of narrative within the organization.

The practical implications of our research are fairly straightforward. Organizations may benefit from establishing formal systems that enable the codification and sharing of narratives. This may increase user interest and perceived value in the knowledge. As a result, knowledge may flow more freely within the organization and across firm boundaries. Moreover, leaders may directly increase interest in narratives by highlighting them-though again, this tactic does not increase the narratives' perceived value, which remains tied to the embedded emotional content.

\section{Conclusion}

The sharing of stories has long proven to be a key mechanism in transferring knowledge. "Storytelling helps us discover something new about the world. It allows us to pass that discovery on to others. And finally, it helps the people who share the story develop a common outlook" (Brown and Duguid, 2000). Stories provide us with far more than lessons learned; they create a common culture and vocabulary, a common outlook that enables us to communicate complex ideas to one another. When paired with technology and organizational support, stories can enable a form of knowledge transfer that is both efficient and effective. When an organization provides people with a structured environment, in which they are free to tell and read stories without bureaucratic oversight or complex technical requirements, effective communication can coexist with 
organizational efficiencies. More importantly, as we have found through our research, organizations can provide knowledge that is both valuable and interesting to the user, by identifying key factors such as emotional content and which stories generate user interest in the field. This research has far-reaching implications for successful knowledge sharing: What is the value of your story? 


\section{References}

Ambos, T.C., Ambos, B., 2009. The impact of distance on knowledge transfer effectiveness in multinational corporations. Journal of International Management 15, 1-14.

Ambos, T.C., Ambos, B., Schlegelmilch, B.B., 2006. Attention headquarters! Business Strategy Review 17(3), 1-2.

Ambos, T.C., Ambos, B., Schlegelmilch, B.B., 2006. Learning from the periphery: an empirical investigation of headquarters' benefits from reverse knowledge transfers. International Business Review 15(3), 294-312.

Anderson, C.W., McMaster, G.E., 1982. Objective analysis of emotional tone in stories and poems. Journal of the Association for Literary and Linguistic Computing 3(2), 45-51.

Bartlett, C.A., 1996. McKinsey \& Co.: Managing Knowledge and Learning. Harvard Business Case, June 28.

Bartlett, C.G., Ghoshal, S., 1989. Managing Across Borders: The Transnational Solution. Harvard Business School Press, Boston.

Beckerman, W., 1956. Distance and the pattern of Intra-European trade. The Review of Economics and Statistics 38(1), 31-40.

Beugelsdijk, S., Frijns, B., 2010. A cultural explanation of the foreign bias in international asset allocation. Journal of Banking and Finance 34, 2121-2131.

Bhardwaj, M., Monin, J., 2006. Tacit to explicit: an interplay shaping organization knowledge. Journal of Knowledge Management 10(3), 72.

Bowman, C., Ambrosini, V., 2001. Tacit Knowledge: Some Suggestions for Operationalization. Journal of Management Studies 38(6), 811-829. 
Brewer, W.F., Lichtenstein, E.H., 1982. Stories are to entertain: A structural-affect theory of stories. Journal of Pragmatics 6(5-6), 473-486.

Brown, J.S., Duguid, P., 2000. Balancing act: how to capture knowledge without killing it. Harvard Business Review 78(3), 73-80.

Brown, J.S., Duguid, P., 2000. The Social Life of Information. Harvard Business School Press, Boston.

Cantwell, J., Mudambi, R., 2005. MNE Competence-Creating Mandates. Strategic Management Journal 26, 1109-1128.

Cantwell, J., Zhang, Y., 2009. The co-evolution of international business connections and domestic technological capabilities: lessons from the Japanese catch-up experience. Transnational Corporations 18(2), 37-68.

Cohen, M.A., Agrawal, N., Agrawal, V., 2006. Winning in the Aftermarket. Harvard Business Review.

Cross, R.L., Parker, A., 2004. The Hidden Power of Social Networks: Understanding How Work Really Gets Done in Organizations. Harvard Business School Press, Boston.

Cyert, R.M., March, J.G., 1992. A Behavioural Theory of the Firm. Blackwell, Cambridge.

Davenport, T.H., 2005. Thinking for a Living: How to Get Better Performance and Results from Knowledge Workers. Harvard Business School Press, Boston.

De Geus, A., 1997. The Living Company: Habits for Survival in a Turbulent Business Environment. Harvard Business School Press, Boston.

Denning, S., 2000. The Springboard: How Storytelling Ignites Action in Knowledge-Era Organizations. Butterworth-Heinemann, Boston.

Disdier, A., Head, K., 2008. The puzzling persistence of the distance effect on bilateral trade. The Review of Economics and Statistics 90(1), 37-48. 
Doz, Y., Santos, J.F.P., 1997. On the management of knowledge: From the transparency of collocation and co-setting to the quandary of dispersion and differentiation. Fontainebleau, France: INSEAD, mimeo.

Fog, K., Budtz, C., Yakaboylu, B., 2005. Storytelling: Branding in Practice. Springer, Berlin.

Foss, N., Pedersen, T., 2004. Organizing Knowledge Processes in the Multinational Corporation: An Introduction. Journal of International Business Studies 35, 340-49.

Fox, R.L., 1973. Alexander the Great. Allen Lane, London.

Frank, C.J., Magnone, P., 2011. Drinking from the Fire Hose: Making Smarter Decisions Without Drowning in Information. Portfolio, London.

Goleman, D., 1995. Emotional Intelligence: Why It Can Matter More Than IQ. Bantam, New York.

Goodall, K., Roberts, J., 2003. Repairing managerial knowledge-ability over distance. Organization Studies 24(7), 1155.

Grant, R.M., 1996. Prospering in dynamically-competitive environments: Organizational capability as knowledge integration. Organizational Science 7, 375-387.

Hansen, M.T., Lovas, B., 2004. How do multinational companies leverage technological competencies? Moving from single to interdependent explanations. Strategic Management Journal 25(8-9), 801-821.

Helfat, C., 1994. Evolutionary Trajectories in Petroleum Firm R\&D. Management Science 40, $1720-1747$.

IFC Corporate Relations. 2010. Where Innovation Meets Impact. IFC Annual Report: World Bank Group. 
Jensen, R., Szulanski, G. 2004. Stickiness and the adaptation of organizational practices in crossborder knowledge transfers. Journal of International Business Studies 35(6), 508-523.

Jensen, R., Szulanski, G., 2007. Template use and the effectiveness of knowledge transfer. Management Science 53(11), 1716-1730.

Kogut, B., Singh, H., 1988. The effect of national culture on the choice of entry mode. Journal of International Business Studies 19(3), 411-432.

Kogut, B., Zander, U., 2003. Knowledge, market failure and the multinational enterprise: a theoretical note. Journal of International Business Studies 26, 399-408.

Kostova, T., Roth, K., 2002. Adoption of an organizational practice by subsidiaries of multinational corporations: institutional and relational effects. Academy of Management Journal 45(1), 215-233.

Lawler, E.J., Yoon, J., 1993. Power and the Emergence of Commitment Behavior in Negotiated Exchange. American Sociological Review 58(4), 465-481.

Lawler, E.J., Yoon, J., 1996. Commitment in Exchange Relations: Test of a Theory of Relational Cohesion. American Sociological Review 61(1), 89-108.

Lawler, E.J., Yoon, J., 1998. Network Structure and Emotion in Exchange Relations. American Sociological Review 63(6), 871-894.

Linde, C., 2001. Narrative and social tacit knowledge. Journal of Knowledge Management, Special Issue on Tacit Knowledge Exchange and Active Learning 5(2), 160-171.

Lehnert, W.G., Vine, E.W., 1987. The role of affect in narrative structure. Cognition and Emotion $1,299-322$.

Makhija, M.V., Ganesh, U., 1997. Control and partner learning in learning related joint ventures. Organization Science 8(5), 508-527. 
March, J.G., Simon, H.A., 1958. Organizations. Wiley Press, New York.

Miall, D.S., 1988. Affect and narrative: a model of response to stories. Poetics 17, 259-272.

Monteiro, F., Arvidsson, N., Birkinshaw, J.M., 2008. Knowledge flows in multinational corporations. Organization Science 19(1), 90-107.

Morris, S.S., Snell, S.A., Wright, P.M., 2006. A resource-based view of international human resources: Toward a framework of integrative and creative capabilities, in: Stahl, G., Bjorkman, I. (Eds.), Handbook of Research in International Human Resource Management. Edward Elgar, Cheltenham, UK, pp. 433-448.

Nahapietand, J., Ghoshal, S., 1998. Social capital, intellectual capital, and the organizational advantage. Academy of Management Review 23, 242-266.

Nelson, R.R., Winter, S.G., 1982. An Evolutionary Theory of Economic Change. Harvard University Press, Cambridge, MA.

Nonaka, I., 1994. A Dynamic Theory of Organizational Knowledge Creation. Organization Science 5(1), 14-37.

Pollock, T.G., Rindova, V.P., 2003. Media legitimation effects in the market for initial public offerings. Academy of Management Journal 46(5), 631-642.

Rosenkopf, L., Nerkar, A., 2001. Beyond local search: boundary-spanning, exploration, and impact in the optical disk industry. Strategic Management Journal 22, 287-306.

Rugman, A.M., Verbeke, A., 2008. A regional solution to the strategy and structure of multinationals. European Management Journal 26, 305-313.

Schreyögg, G., Geiger, D., 2005. Developing organizational narratives: a new dimension in knowledge management, in: Renzl, B., Matzler, K., Hinterhuber, H. (Eds.), The Future of Knowledge Management. Palgrave, London, pp. 82-98. 
Schreyögg, G., Geiger, D., 2007. The Significance of Distinctiveness: A Proposal for Rethinking Organizational Knowledge. Organization 14(1), 77-100.

Schulz, M., 2003. Pathways of relevance: exploring inflows of knowledge into subunits of multinational corporations. Organization Science 14, 440-459.

Shaw, G., Brown, R., Bromiley, P., 1998. Strategic stories: how 3M is rewriting business planning. Harvard Business Review 76(May-June), 41-50.

Snowden, D., 1999. Three metaphors, two stories and a picture-how to build common understanding in knowledge management programmes. Knowledge Management Review, March-April.

Snowden, D., 1999. Story telling for the capture and communication of tacit knowledge. Business Information Review (1 of 2).

Snowden, D., 2002. Narrative patterns: uses of story in the third age of knowledge management. Journal of International Knowledge Management 1(1), 1-6.

Snowden, D., 2003. Complex acts of knowing: paradox and descriptive self-awareness. Bulletin of the American Society for Information Science and Technology 29, 23-28.

Stewart, T.A., 2001. The Wealth of Knowledge: Intellectual Capital and the Twenty-First Century Organization. Doubleday, New York.

Stuart, T., Podolny, J., 1996. Local search and the evolution of technological capabilities. Strategic Management Journal 17(Summer Special Issue), 21-38.

Swap, W., Leonard, D., Shields, M., Abrams, L., 2001. Using mentoring and storytelling to transfer knowledge in the workplace. Journal of Management Information Systems 18, 95114. 
Szulanski, G., Jensen, R., 2006. Presumptive adaptation and the effectiveness of knowledge transfer. Strategic Management Journal 10(27), 937-957.

Thomas, J., 1999. Narrative technology and the new millennium. Knowledge Management Journal 2(9), 14-17.

Turner, K., Makhija, M., 2006. The Relationship Between Organizational Control Systems and a Firm's Management of Knowledge. Academy Management Review 31, 197-217.

Weick, K.E., 1995. Sensemaking in Organizations. Sage, Thousand Oaks, CA.

Weick, K.E., Roberts, K.H., 1993. Collective Mind in Organizations: Heedful Interrelating on Flight Decks. Administrative Science Quarterly 38(3), 357-381.

Zaheer, S., 1995. Overcoming the Liability of Foreignness. Academy of Management Journal 38, $341-364$.

Zaheer, S., Manrakhan, S., 2001. Concentration and Dispersion in Global Industries: Remote Electronic Access and the Location of Economic Activities. Journal of International Business Studies 32(4), 667-686. 


\section{Biographies}

Shad Morris (PhD Cornell University) is the Georgia White Fellow and Assistant Professor of Organizational Leadership and Strategy at the Marriott School of Management, Brigham Young University. Morris has published articles in Academy of Management Review, Journal of International Business Studies, Journal of Operations Management, Harvard Business Review, Sloan Management Review and Human Resource Management. He has also coauthored a book, Managing People and Knowledge in Professional Service Firms. His research examines the intersection of people and knowledge. Email: morris@byu.edu

James Oldroyd (PhD Northwestern University) is Assistant Professor of Management and Human Resources at the Fisher College of Business, The Ohio State University. Oldroyd has published multiple articles in Academy of Management Review, Organization Science, Harvard Business Review, Sloan Management Review, Strategic Entrepreneurship Journal and Personality and Social Psychology Bulletin. His research examines how information flows through social networks within organizations. Email: oldroyd@ fisher.osu.edu

Sita Ramaswami (MBA University of Pennsylvania, MA University of Cambridge) has served as Manager of South Investments at IFC in Mumbai, India. Previously, she was the Manager of Knowledge Management and Learning Services in the Small and Medium Enterprise Department in IFC in Washington D.C., where she developed the SmartLessons Program. Email: sramaswami@ifc.org 